\title{
KONSUMSI AIR DAN PRODUKSI KARET PADA BERBAGAI SISTEM PENGATURAN JARAK TANAM DALAM KAITANNYA DENGAN KANDUNGAN AIR TANAH
}

\author{
Water Consumption and Rubber Production on Various Planting Space Arrangement \\ System and Their Relationship with Soil Water Content
}

Andi Nur CAHYO, Risal ARDIKA, dan Thomas WIJAYA

Balai Penelitian Sembawa, Pusat Penelitian Karet

Jalan Raya Palembang - P. Balai KM 29, PO BOX 1127 Palembang 30001

Diterima tgl. 24 Agustus 2011/Disetujui 29 Nopember 2011

\begin{abstract}
Water shortage during the dry season caused rubber plant shed the leaves as to an effort to reduce soil moisture use. The aim of research was to obtain the most efficient planting space arrangement system in relationship with soil water extraction, so that in the dry season moisture competition could be reduced. The treatment in this research were monoculture with normal planting space (A), monoculture with double row space (B), and intercropping (double row space + RRIC 100 clone) (C). Treatment was arranged in Randomized Completely Block Design with four replications. Observations was conducted on soil water content, rubber yield, wintering time, specific leaf area, and leaf area index. Observation on soil water content showed that there were no significant differences between soil water content in all treatments because of high total rainfall, but in dry season there were differences in water extraction pattern i.e. $C$ treatment consumed water more quickly because of high LAI. Dry rubber production in $C$ treatment was significantly lower than others, whereas A treatment was the highest. The low dry rubber production in C treatment was caused by leaf area per tree is only about $50 \%$ from the other treatments. The low leaf area per tree for $C$ treatment was caused by planting density material treatment is too high, which is reach more than twice of $A$ and $B$ treatments.
\end{abstract}

Keywords: Hevea brasiliensis, planting space, soil water content, leaf area index, wintering, production

\section{Abstrak}

Kekurangan air pada saat musim kemarau menyebabkan tanaman karet menggugurkan daunnya sebagai upaya adaptasi untuk mengurangi kebutuhan air. Tujuan penelitian adalah untuk mengetahui sistem pengaturan jarak tanam yang paling efisien dalam hubungannya dengan ekstraksi air tanah, sehingga pada saat musim kemarau kompetisi air tanah dapat dikurangi. Perlakuan dalam penelitian ini ialah monokultur dengan jarak tanam normal (A), monokultur dengan jarak tanam ganda (B), dan tumpangsari (jarak tanam ganda + klon RRIC 100) (C). Perlakuan tersebut disusun dalam rancangan acak kelompok dengan 4 ulangan. Pengamatan dilakukan terhadap parameter kadar air tanah, produksi karet, waktu terjadinya gugur daun, luas daun spesifik, dan indeks luas daun. Pengamatan terhadap kadar air tanah menunjukkan bahwa tidak terdapat beda nyata antara kadar air tanah pada semua perlakuan karena curah hujan total yang tinggi, namun pada musim kemarau terjadi perbedaan pola ekstraksi air yaitu perlakuan $\mathrm{C}$ mengkonsumsi air lebih cepat karena ILD yang tinggi. Produksi karet kering perlakuan $\mathrm{C}$ nyata lebih rendah daripada perlakuan yang lain, sedangkan perlakuan A adalah yang tertinggi. Rendahnya produksi karet kering perlakuan $\mathrm{C}$ disebabkan karena luas daun per pohon hanya sekitar $50 \%$ dari luas daun perlakuan yang lainnya. Rendahnya luas daun per pohon untuk perlakuan $\mathrm{C}$ ini diduga disebabkan karena terlalu tingginya kerapatan tanam yang mencapai lebih dari dua kali kerapatan tanam perlakuan A dan B.

Kata kunci : Hevea brasiliensis, jarak tanam, kadar air tanah, indeks luas daun, gugur daun, produksi 


\section{PENDAHULUAN}

Tanaman karet merupakan tanaman yang mempunyai daya adaptasi luas dan dapat tumbuh pada berbagai kondisi tanah dan iklim, namun pertumbuhannya akan lebih optimal jika ditanam pada daerah yang mempunyai kondisi lingkungan yang lebih sesuai. Dari segi iklim, tanaman karet akan tumbuh secara optimum jika dibudidayakan dalam lingkungan yang mempunyai iklim sebagai berikut : (1) curah hujan sekitar $2000 \mathrm{~mm} /$ tahun atau lebih yang terdistribusi secara merata tanpa diselingi musim kemarau dengan sekitar 125 hingga 150 hari hujan per tahun; (2) suhu udara $20^{\circ} \mathrm{C}$ hingga $34^{\circ} \mathrm{C}$ dengan rata-rata bulanan $25^{\circ} \mathrm{C}$ hingga $28^{\circ} \mathrm{C}$; (3) kelembaban udara sekitar 80\% dengan kecepatan angin sedang; (4) intensitas sinar matahari yang tinggi selama sekitar 2000 jam per tahun dengan lama penyinaran 6 jam per hari sepanjang bulan (Webster dan Baulkwill, 1989 dalam Vijayakumar et al., 2000).

Di Indonesia, anasir iklim yang ideal untuk pertumbuhan optimum bagi tanaman karet tersebut tidak dapat terpenuhi sepanjang tahun karena adanya musim kemarau. Pada saat musim kemarau, ketersediaan air berkurang sehingga air menjadi faktor pembatas bagi pertumbuhan dan produksi tanaman karet. Hal ini terutama terjadi pada pertanaman karet yang pengaturan jarak tanamnya terlalu rapat, sehingga terjadi kompetisi antar tanaman karet dalam mengkonsumsi air tanah. Pengaruh ketersediaan air terhadap produksi karet sangat besar karena sekitar 60-70\% dari lateks adalah air. Menurut Chang (1968) kekurangan air akan berakibat berkurangnya laju fotosintesis karena dehidrasi protoplasma.

Turunnya kadar air tanah pada saat musim kemarau akan mempengaruhi penyerapan air dan unsur hara, yang selanjutnya akan mempengaruhi metabolisme dan pertumbuhan tanaman. Salah satu fungsi utama air bagi tanaman adalah untuk mempertahankan turgiditas sel dan jaringan tanaman yang penting artinya bagi kelangsungan aktivitas sel dalam pembelahan dan pemanjangan (Wargadipura dan Harran, 1984). Kramer (1983) menyatakan bahwa pengaruh yang langsung akibat kekurangan air berkepanjangan adalah berkurangnya laju pertumbuhan sehingga ukuran tanaman dan produksi lebih rendah dibandingkan tanaman normal.

Cekaman air berakibat pada beberapa perubahan dalam proses kehidupan tanaman karet diantaranya adalah : reduksi pertumbuhan seperti lilit batang, biomassa batang atas, ujung akar, akar serabut, dan bobot kering tanaman. Reduksi organ asimilasi seperti helaian daun dan luas daun, reduksi status air, refleksinya melalui penurunan bobot kering daun, bertambahnya stomata, dan lain-lain (Setiawan et al., 2000 dalam Indraty, 2003). Menurut Shock (1982) dalam Wargadipura dan Harran (1984), pada keadaan air tanah mendekati kapasitas lapang, aktivitas pembuluh sel tanaman maupun translokasi asimilat akan terpacu. Akibatnya pertumbuhan daun akan dipercepat sehingga luas permukaan daun dapat bekembang pesat.

Pengaruh tingkat kadar air tanah sangat nyata terhadap bobot kering tanaman karet. Disamping sebagai bahan baku proses fotosintesis, air bertindak pula sebagai pelarut, reagensia pada berbagai macam reaksi dan sebagai pemelihara turgor. Hanya sebagian kecil $(<1 \%)$ air yang diabsorbsi tanaman dipergunakan dalam reaksi metabolisme. Sebagian besar dari air tanah yang diabsorbsi oleh akar tanaman akan ditranspirasikan melalui stomata. Kekurangan air dalam tanaman terjadi bila kehilangan air melalui transpirasi lebih besar dari serapan air melalui akar (Husni dan Aidi-Daslin, 1995). Kehilangan air dari dalam tanah selain melalui transpirasi dapat juga melalui proses evaporasi. Kehilangan air melalui evaporasi permukaan tanah dianggap sebagai kehilangan air yang tidak produktif karena tidak berkaitan dengan proses yang terjadi di dalam tanaman, sedangkan transpirasi merupakan kehilangan air yang produktif (Thomas, 1995).

Kekurangan air pada saat musim kemarau diduga menyebabkan tanaman karet beradaptasi dengan cara menggugurkan daunnya. Hal ini menyebabkan kapasitas fotosintesis tanaman karet menurun, sehingga produksi lateksnya juga menurun. Penurunan produksi paling besar terjadi pada waktu pembentukan daun baru (Thomas dan Boerhendhy, 1988). 
Dalam hubungannya dengan penyerapan air, organ tanaman karet yang perlu diperhatikan adalah akar. Akar sebagai salah satu organ tanaman berfungsi menyerap air serta garam-garam mineral dan oksigen dari dalam tanah dan meneruskannya ke batang dan daun. Sebaliknya ketersediaan air akan melarutkan garam-garam mineral yang ada di sekitar akar yang diperlukan untuk pertumbuhan tanaman termasuk akar. Kramer (1983) menyatakan bahwa, kekurangan air akan mengubah translokasi asimilat ke arah akar lebih banyak, sebagai respons dari tanaman untuk memperluas sistem perakarannya.

Pada pola tanam karet dengan tanaman sela, akar tanaman karet akan berinteraksi dengan akar tanaman sela dalam memanfaatkan air dan unsur hara yang tersedia dalam tanah (Wibawa et al., 1999), sehingga pengaturan jarak tanam akan sangat berpengaruh terhadap pertumbuhan dan produksi tanaman karet. Dengan jarak tanam yang tepat, air yang ada akan termanfaatkan secara optimal sehingga produktivitas optimal akan didapatkan dari suatu lahan.

Tingginya kompetisi antar tanaman karet dalam penyerapan air tanah pada saat musim kemarau dapat dikurangi dengan pengaturan jarak tanam yang tepat. Pengaturan jarak tanam akan sangat berpengaruh terhadap pertumbuhan dan produksi tanaman karet. Dalam hubungannya dengan pengaturan jarak tanam, pada populasi yang lebih tinggi, kontak antar akar tanaman lebih cepat terjadi sehingga kompetisi dalam mendapatkan air akan meningkat terutama pada saat musim kemarau.

Selain itu Leong dan Yoon (1982) mengatakan bahwa pada populasi yang tinggi, cabang-cabang dan daun-daun yang berada pada bagian bawah lebih ternaungi. Cabang-cabang yang ternaungi tersebut tidak akan optimal dalam melakukan fotosintesis dan justru akan ikut berperan dalam meng-konsumsi assimilat yang dihasilkan oleh bagian tanaman yang lebih optimal dalam melakukan fotosintesis. Oleh karena itu untuk mendapatkan hasil yang optimal dari suatu lahan diperlukan pengaturan jarak tanam yang tepat. Dengan jarak tanam yang tepat, air dan cahaya yang ada akan termanfaatkan secara optimal sehingga produktivitas yang optimal juga akan didapatkan dari suatu lahan.

\section{BAHAN DAN METODE}

Bahan yang digunakan dalam penelitian ini adalah tanaman karet klon BPM 24 dan RRIC 100 yang ditanam dengan berbagai pengaturan jarak tanam. Alat yang digunakan adalah pengukur kadar air tanah Troxler Sentry 200 AP, lux meter, litter trap, oven, dan pralon. Penelitian dilaksanakan di Kebun Percobaan Balai Penelitian Sembawa pada jenis tanah Podzolik Merah Kuning dari bulan Januari hingga Desember 2010. Penelitian menggunakan percobaan pada areal karet yang ditanam dengan sistem monoklonal dan duoklonal. Perlakuannya ialah monoklonal BPM 24 dengan jarak tanam normal (A), monoklonal BPM 24 dengan jarak tanam ganda (B), dan pola tanam duoklonal BPM 24 + RRIC 100) (C). Perlakuan tersebut disusun dalam rancangan acak kelompok dengan 4 ulangan.

Pengamatan kadar air tanah dilakukan dengan cara menanam pipa pralon ke areal pertanaman karet pada posisi yang telah ditentukan (Gambar 1). Pipa pralon yang digunakan sepanjang $1 \mathrm{~m}$ ditanam ke masing-masing blok/ulangan dalam setiap perlakuan. Pipa pralon tersebut digunakan sebagai wadah untuk memasukkan sensor pengukur kadar air tanah hingga diperoleh kedalaman yang sesuai dengan aman. Pengamatan dilaksanakan seminggu sekali.

Parameter yang diamati meliputi :

\section{Kadar Air Tanah}

Pengamatan kadar air tanah dilakukan dengan memasukkan sensor alat pengukur kadar air tanah (Sentry 200 AP) ke dalam pralon dengan kedalaman $1 \mathrm{~m}$. Hasil pengukuran tersebut dibaca pada layar alat pengukur kadar air tanah dengan satuan (\%). Pengukuran kadar air tanah ini dilakukan seminggu sekali. Konsumsi air dihitung dengan melihat penambahan total kandungan air tanah sedalam $1 \mathrm{~m}$ dan ditambahkan dengan besarnya curah hujan. 

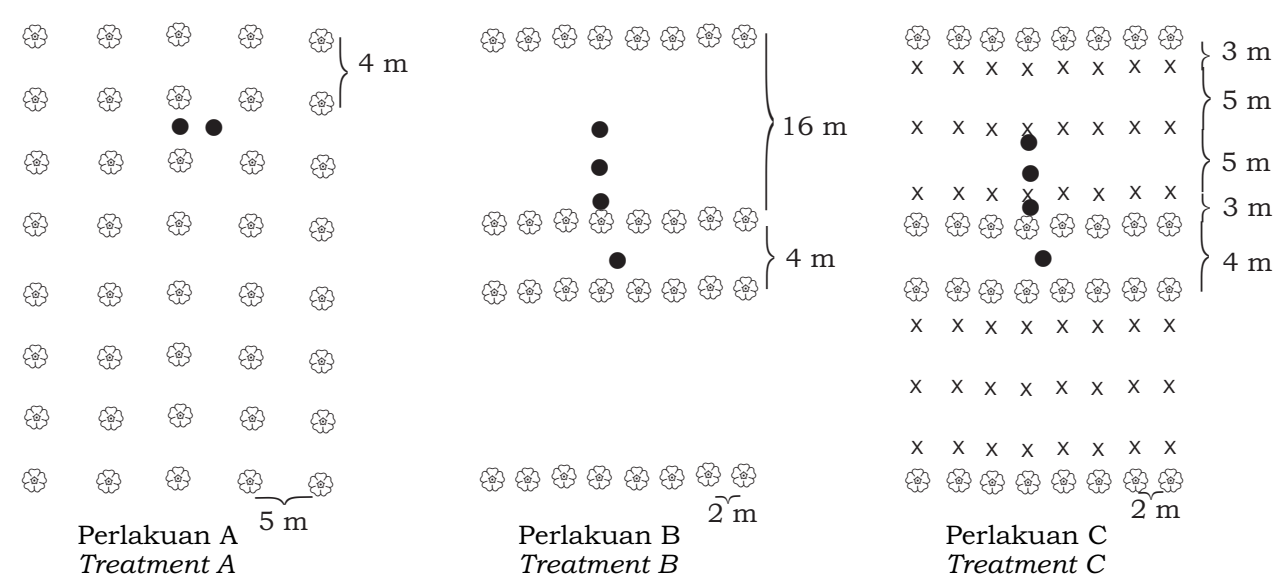

Keterangan (Remarks):

紓= Tanaman karet klon BPM 24 (Rubber plant of clone BPM 24)

$\mathrm{x}=$ Tanaman karet klon RRIC 100 (Rubber plant of clone RRIC 100)

- = Pralon tempat sensor pengukur kadar air tanah (Access tube for placing soil water content sensor)

Gambar 1. Tata letak penempatan sensor pengukur kadar air tanah di lapangan

Figure 1. Soil water content measurer censor lay out in the field

\section{Produksi Karet}

Pengamatan produksi karet dilakukan dengan mengukur hasil sadapan setiap minggu dengan satuan gram $(\mathrm{g})$.

\section{Waktu Terjadinya Gugur Daun}

Pengamatan waktu terjadinya gugur daun dilakukan dengan cara mencatat tanggal terjadinya daun yang mulai menguning hingga habis karena gugur daun.

\section{Luas Daun Spesifik}

Pengamatan Luas Daun Spesifik (LDS) dilakukan dengan rumus sebagai berikut (Gardner et al., 1985):

$$
\operatorname{LDS}=\frac{\text { Luas daun }\left(\mathrm{cm}^{2}\right)}{\text { Bobot daun }(\mathrm{g})}
$$

Pengukuran luas daun dilakukan dengan metode litter trap. Daun yang diukur luasnya hanya daun yang terjatuh pada litter trap, yaitu daerah seluas $1 \mathrm{~m} \times 1 \mathrm{~m}\left(1 \mathrm{~m}^{2}\right)$ dimana daerah tersebut ternaungi oleh daun.

\section{Indeks Luas Daun}

Pengamatan Indeks Luas Daun (ILD) dilakukan dengan rumus sebagai berikut (Gardner et al., 1985):

$$
\operatorname{ILD}=\frac{\text { Luas daun }\left(\mathrm{cm}^{2}\right)}{\text { Luas litter trap }\left(10000 \mathrm{~cm}^{2}\right)}
$$

Analisis statistika yang digunakan dalam penelitian ini adalah rancangan pembedaan rerata dengan uji jarak berganda Duncan taraf 5\%. Selain itu juga dilakukan analisis tentang kaitan produksi dengan ILD dan kadar air tanah, kaitan sistem pertanaman dengan ekstraksi air tanah, dan kaitan status air tanaman dengan sistem pertanaman.

\section{HASIL DAN PEMBAHASAN}

Pengamatan terhadap kadar air tanah menunjukkan bahwa tidak terdapat beda nyata antar perlakuan (Gambar 2). Tidak adanya beda nyata kadar air tanah antar perlakuan diduga disebabkan karena selama periode pengamatan dilakukan masih sering terjadi hujan, sehingga besarnya curah hujan yang diserap tanah masih lebih tinggi dari laju transpirasi maksimum tanaman. Hal ini berakibat 


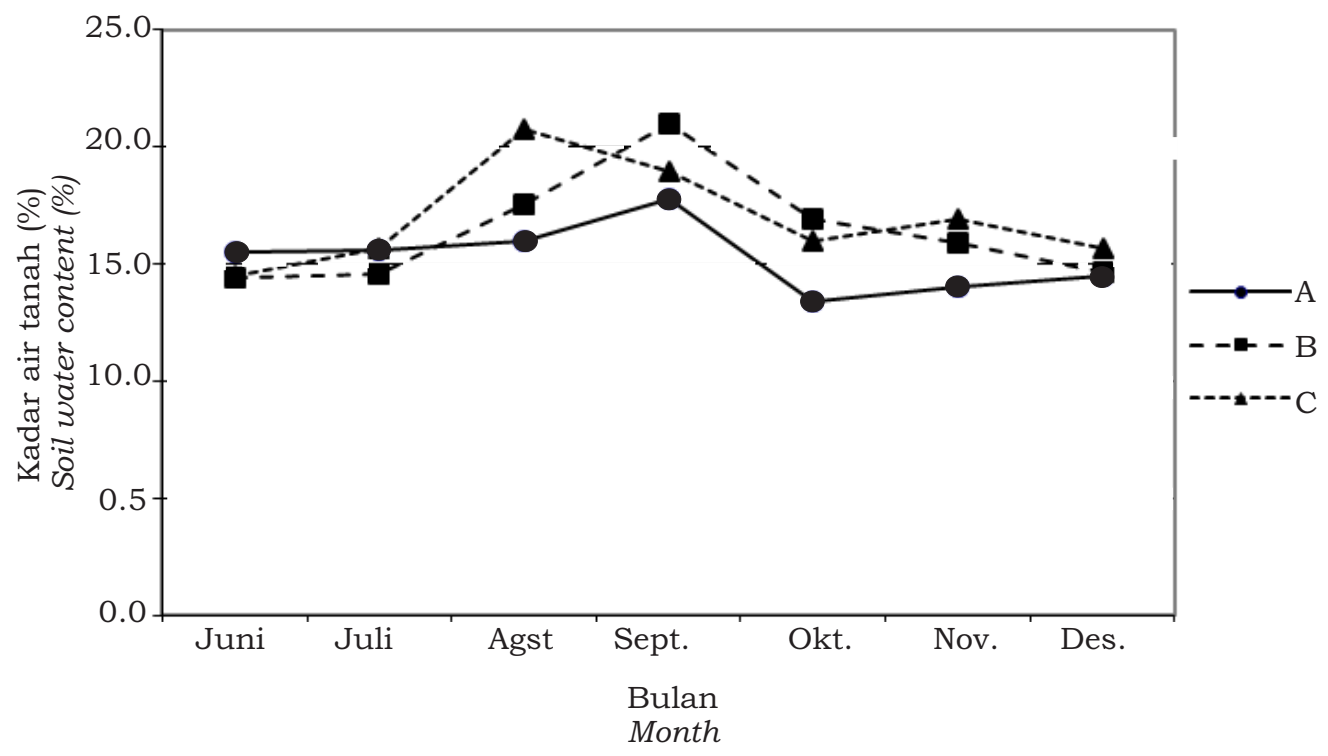

Gambar 2. Hubungan kadar air tanah dengan waktu

Figure 2. Relationship between soil water content and time

tingginya populasi tanaman pada perlakuan $\mathrm{C}$ belum berpengaruh terhadap penurunan kadar air tanah, walaupun konsumsi air perlakuan $\mathrm{C}$ nyata lebih tinggi dari pada perlakuan A pada bulan Juni (Tabel 1). Dari Tabel 1. juga terlihat bahwa pada bulan Agustus ketika curah hujan sangat rendah dan ILD mendekati 0 (Gambar 3), konsumsi air perlakuan $\mathrm{C}$ menjadi lebih rendah dari pada perlakuan A dan B. Hal ini disebabkan karena bulan Agustus nilai ILD perlakuan C turun hingga di bawah 1 karena adanya gugur daun (Gambar 3), sehingga luas daun per pohonnya menjadi paling rendah (Gambar 4). Hal ini mengakibatkan laju transpirasi dan konsumsi air perlakuan C menjadi yang paling rendah.

Dari Tabel 1 juga terlihat bahwa pada bulan Agustus ketika curah hujan sangat rendah dan ILD telah mencapai 0 (Gambar 3), konsumsi air perlakuan $C$ menjadi lebih rendah dari pada perlakuan A dan B. Hal ini dikarenakan air telah terekstrasi dalam jumlah besar pada bulan-bulan sebelumnya akibat penggunaan air yang tinggi oleh tanaman yang berkaitan dengan ILD yang tinggi pada perlakuan $\mathrm{C}$.

Dari Gambar 3 juga terlihat bahwa ILD perlakuan C dari bulan Mei hingga Juli nyata lebih tinggi daripada perlakuan yang lain dan mulai menjadi sama pada minggu ke-2 bulan Agustus. Pada semua perlakuan, ILD menurun drastis pada minggu ke-3 bulan Juli. Hal ini diduga disebabkan karena pada bulan Juli, dari tanggal 3 - 25 hanya terjadi 4 kali hujan dengan curah hujan yang sangat rendah $(2,3-11,4 \mathrm{~mm})$ dan tiba-tiba terjadi hujan lebat pada tanggal $26(108 \mathrm{~mm})$. Hujan lebat yang terjadi setelah 3 minggu periode kering tersebut diduga telah memicu gugurnya daun secara serentak sehingga meng-akibatkan ILD menurun tajam. Penurunan ILD ini diikuti dengan penurunan produksi (Gambar 4).

Dari Gambar 4, terlihat bahwa produksi karet kering per pohon pada perlakuan $\mathrm{C}$ nyata lebih rendah dari perlakuan yang lain, sedangkan untuk perlakuan A adalah yang paling tinggi. Produksi pada perlakuan A tinggi disebabkan kondisi jarak tanam yang ideal sehingga membuat proses fotosintesis tanaman dapat berlangsung secara maksimal dan berakibat pada tingginya produksi. Rata-rata produksi pada perlakuan A, B, C berturut-turut selama 8 bulan adalah $39,69 \mathrm{~g} / \mathrm{p} / \mathrm{s} ; 35,72 \mathrm{~g} / \mathrm{p} / \mathrm{s}$, dan $15,39 \mathrm{~g} / \mathrm{p} / \mathrm{s}$. Rendahnya produksi karet kering perlakuan $\mathrm{C}$ disebabkan karena luas daun per pohon perlakuan $\mathrm{C}$ hanya sekitar setengah dari luas daun perlakuan yang lainnya. Rendahnya luas daun per pohon untuk perlakuan $\mathrm{C}$ ini diduga disebabkan 


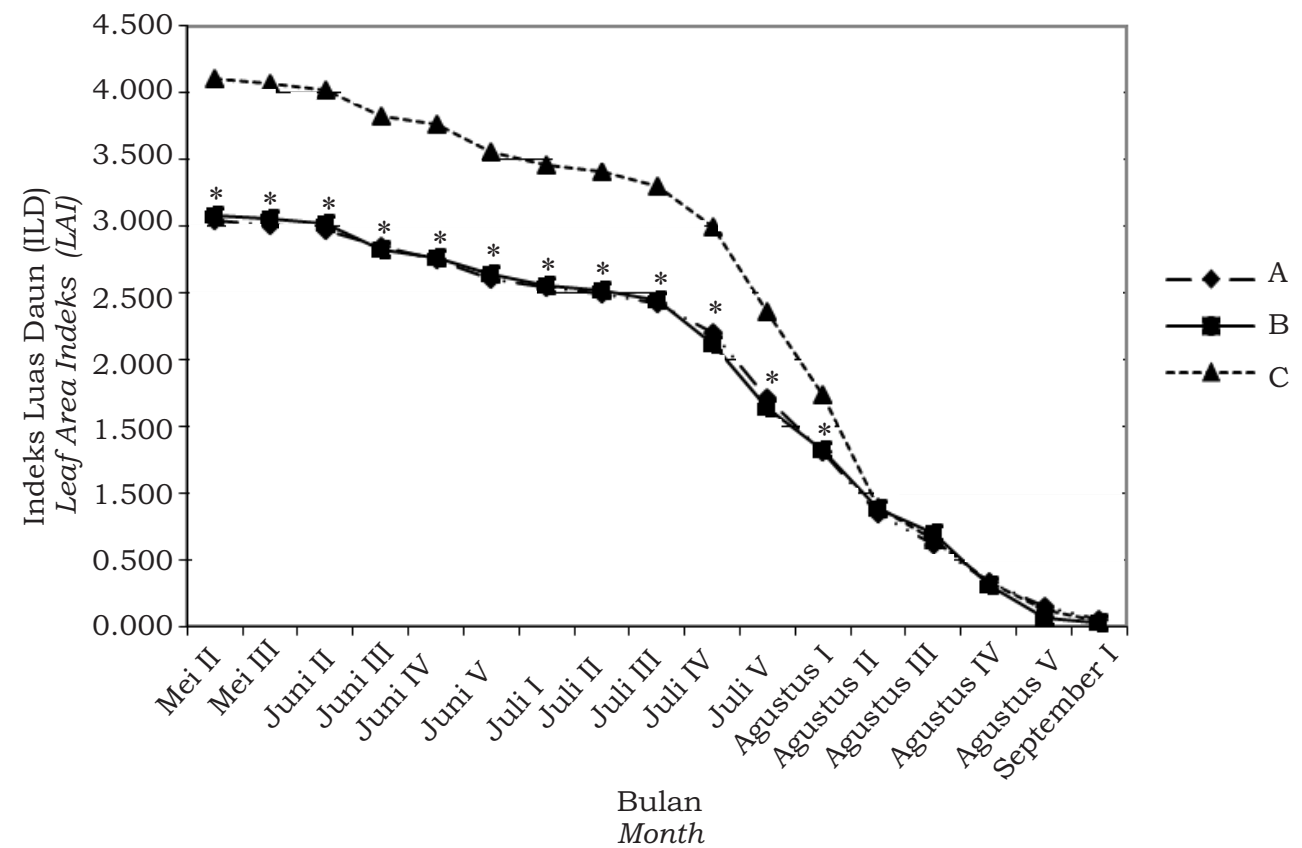

Keterangan (Remarks):

Grafik yang terpisah oleh tanda * menunjukkan adanya beda nyata menurut uji jarak berganda Duncan pada tingkat signifikasi 5\% (Line separated by * are significantly different at DMRT 5\%)

Gambar 3. Hubungan indeks luas daun dengan waktu

Figure 3. Relationship between leafarea index and time

Tabel 1. Pengaruh sistem pengaturan jarak tanam terhadap konsumsi air Table 1. The effect of planting space arrangement system to water consumption

\begin{tabular}{cccrc}
\hline \multirow{2}{*}{$\begin{array}{c}\text { Perlakuan } \\
\text { Treatment }\end{array}$} & \multicolumn{4}{c}{$\begin{array}{c}\text { Konsumsi air pada bulan } \\
\text { Water consumption each month } \\
\text { mm }\end{array}$} \\
\cline { 2 - 5 } & Juni & Juli & Agustus & Total \\
\hline A & $68,25 \mathrm{~b}$ & $155,68 \mathrm{~b}$ & $116,18 \mathrm{a}$ & $340,11 \mathrm{c}$ \\
B & $113,20 \mathrm{ab}$ & $150,62 \mathrm{~b}$ & $105,07 \mathrm{~b}$ & $368,89 \mathrm{~b}$ \\
$\mathrm{C}$ & $126,51 \mathrm{a}$ & $229,86 \mathrm{a}$ & $76,43 \mathrm{c}$ & $432,80 \mathrm{a}$ \\
\hline
\end{tabular}

Angka yang diikuti huruf yang berbeda pada kolom yang sama menunjukkan adanya beda nyata menurut uji jarak berganda Duncan pada tingkat signifikan $5 \%$.

Value followed by the different letter in the same column are significantly different at DMRT 5\%.

karena terlalu tingginya kerapatan tanam perlakuan $\mathrm{C}$ karena keberadaan tanam sela.

Untuk perlakuan B dan C penurunan produksi karet kering hingga mencapai titik minimum dimulai ketika nilai luas daun menurun secara tajam pada bulan Juli, namun untuk perlakuan A, penurunan produksi dimulai ketika luas daun turun secara bertahap pada bulan Juni. Hal ini menunjukkan bahwa distribusi tajuk pada perlakuan A adalah yang paling ideal, karena semua bagian tajuk mendapatkan sinar matahari yang cukup untuk berfotosintesis sehingga pengurangan sedikit jumlah daunnya telah berpengaruh pada penurunan produksi karet kering. Pada perlakuan $\mathrm{B}$ dan $\mathrm{C}$ ada sebagian tajuk yang 
saling menutup sehingga bagian tajuk yang ternaungi laju fotosintesisnya tidak optimal. Pada waktu gugur daun terjadi secara bertahap, tajuk yang semula ternaungi menjadi terbuka sehingga tercapai laju fotosintesis yang optimal. Hal ini mengakibatkan produksi karet kering belum mengalami penurunan walaupun telah terjadi gugur daun secara bertahap. Hal ini juga menunjukkan bahwa distribusi tajuk untuk perlakuan B dan C kurang ideal karena masih ada tajuk tanaman yang saling menaungi.

Pada semua perlakuan, titik minimum produksi karet kering terjadi pada bulan September saat daun baru mulai tumbuh namun belum mampu melakukan fotosintesis. Hal ini disebabkan karena cadangan makanan pada tanaman karet dipergunakan untuk pertumbuhan dan perkembangan daun baru tersebut sehingga alokasi cadangan makanan yang digunakan untuk pembentukan lateks menjadi berkurang.

Rendahnya produksi karet kering pada perlakuan $\mathrm{C}$ dibanding perlakuan yang lain diduga bukan disebabkan karena kompetisi dalam hal konsumsi air terutama pada musim hujan, namun lebih disebabkan karena kompetisi dalam pengambilan cahaya dan unsur hara. Hal ini dapat terjadi karena pada perlakuan $\mathrm{C}$ terdapat tanaman sela yang menjadi kompetitor bagi tanaman utama dalam mendapatkan cahaya dan unsur hara dari dalam tanah sehingga laju fotosintesis perlakuan C lebih rendah daripada perlakuan yang lain. Rendahnya laju fotosintesis ini juga menyebabkan tebal kulit dan lilit batang perlakuan $\mathrm{C}$ lebih rendah dari pada perlakuan yang lain (Tabel 2).

\section{KESIMPULAN}

Pada musim hujan tidak terdapat beda nyata kadar air tanah pada semua perlakuan, namun pada periode kemarau terjadi perbedaan kadar air yaitu perlakuan $\mathrm{C}$ paling tinggi dalam mengkonsumsi air sedangkan produksi karet kering tertinggi dijumpai pada perlakuan kontrol (A) sebesar $39,69 \mathrm{~g} / \mathrm{p} / \mathrm{s}$. Produksi karet kering terendah terjadi pada saat periode pembentukan daun baru yang belum mampu melakukan fotosintesis secara maksimal, dan adanya kompetisi penggunaan cahaya asimilat antara produksi lateks dan pembentukan daun.

\section{DAFTAR PUSTAKA}

Chang, J. H. 1968. Climate and Agriculture. University of Hawaii. 303p.

Gardner, F. P., R. B. Pearce, and R. L. Mitchell. 1985. Physiology of Crop Plants. The Iowa State University Press. Iowa.

Husni, Z. dan Aidi-Daslin. 1995. Pengaruh kadar air tanah terhadap pertumbuhan bibit karet dalam polibeg. J. Penel. Karet, 13 (1), 32-39.

Indraty, I. S. 2003. Ketahanan bibit klon karet dalam polibeg terhadap kondisi kekurangan air. J. Penel. Karet, 21 (1), 12-24.

Kramer. 1983. Water Relations of Plants. Academic Press Inc. Orlando, Florida.

Leong, W. and P. K. Yoon. 1982. Modification of crown development of Hevea brasiliensis Muell. Arg. by cultural practices. II. Tree density. J. Rubb. Res. Inst Malaysia , 30 (3), 123-130.

Setiawan, A., H. Kuswanto, dan B.H. Simanjuntak. 2000. Tanggapan beberapa klon karet terhadap cekaman air di bibitan polibeg. Agric. 14 (1).

Shock, C. C. 1982. Rebaudi's Stevia : natural non caloric sweeteners. California Agriculture, 36 (9.10), 4-5.

Thomas dan I. Boerhendhy. 1988. Hubungan neraca air tanah dengan produksi karet klon GT 1 dan PR 261. Bull. Perkebunan Rakyat, 4 (1), 15-18.

Thomas. 1995. Pengaruh mulsa terhadap pertumbuhan dan efisiensi penggunaan air bibit karet klon GT 1. J. Penel. Karet, 13 (1), 40-48. 
Vijayakumar, K.R., T.R. Chandrashekar, and V. Philip. 2000. Agroclimate. In: George, P. J. and C. K. Jacob (eds). Natural Rubber : Agromanagement and Crop Proc.. Rubb. Res. Inst. India. Kottayam, Kerala, India.

Wargadipura, R. dan S. Harran. 1984. Pengaruh tegangan air tanah terhadap pertumbuhan dan hasil tanaman stevia asal stek dan biji. Bull. Agronomi XV $(1 \& 2)$.
Wibawa, G., M. J. Rosyid, dan A. Gunawan. 1999. Tumpangsari Berbasis Karet. Pusat Penelitian Karet. Sumatera Selatan. 